\title{
A review of demand side flexibility potential in Northern Europe
}

Söder, Lennart; Lund, Peter D.; Koduvere, Hardi; Bolkesjø, Torjus Folsland; Rossebø, Geir Høyvik; Soysal, Emilie Rosenlund; Skytte, Klaus; Katz, Jonas; Blumberga, Dagnija

\section{Published in:}

Renewable and Sustainable Energy Reviews

Link to article, DOI:

10.1016/j.rser.2018.03.104

Publication date:

2018

Document Version

Peer reviewed version

Link back to DTU Orbit

Citation (APA):

Söder, L., Lund, P. D., Koduvere, H., Bolkesjø, T. F., Rossebø, G. H., Soysal, E. R., Skytte, K., Katz, J., \& Blumberga, D. (2018). A review of demand side flexibility potential in Northern Europe. Renewable and

Sustainable Energy Reviews, 91, 654-664. https://doi.org/10.1016/j.rser.2018.03.104

\section{General rights}

Copyright and moral rights for the publications made accessible in the public portal are retained by the authors and/or other copyright owners and it is a condition of accessing publications that users recognise and abide by the legal requirements associated with these rights.

- Users may download and print one copy of any publication from the public portal for the purpose of private study or research.

- You may not further distribute the material or use it for any profit-making activity or commercial gain

- You may freely distribute the URL identifying the publication in the public portal 


\title{
A review of demand side flexibility potential in Northern Europe ${ }^{\text {is }}$
}

\author{
Lennart Söder ${ }^{\mathrm{a}, *}$, Peter D. Lund ${ }^{\mathrm{b}}$, Hardi Koduvere ${ }^{\mathrm{c}}$, Torjus Folsland Bolkesj $\varnothing^{\mathrm{d}}$, \\ Geir Høyvik Rosseb $\varnothing^{\mathrm{d}}$, Emilie Rosenlund-Soysal ${ }^{\mathrm{e}}$, Klaus Skytte ${ }^{\mathrm{e}}$, Jonas Katz ${ }^{\mathrm{e}}$, Dagnija Blumberga ${ }^{\mathrm{f}}$ \\ ${ }^{\text {a }}$ KTH - Royal Institute of Technology, Sweden \\ ${ }^{\mathrm{b}}$ Aalto University, Finland \\ c Tallinn University of Technology, TTU, Estonia \\ ${ }^{\mathrm{d}} \mathrm{NMBU}$, Norway \\ e $D T U$, Denmark \\ ${ }^{\mathrm{f}} \mathrm{RTU}$, Latvia
}

\section{A R T I C L E I N F O}

\section{Keywords:}

Wind power

Solar power

Flexibility

Demand side management

Balancing

\begin{abstract}
A B S T R A C T
The number of regional and national power systems with a high share of wind and solar power in the world is quickly increasing. The background for this development is improved technology, decreasing costs, and increased concern regarding environmental problems of competing technologies such as fossil fuels. For the future there are large possibilities for increasing the renewable electricity share. However, variable renewable power production has to be balanced. Demand side flexibility offers an interesting approach to the balancing issues. The aim of this paper is to compare flexibility potentials and how they were estimated in seven Northern European countries in order to compare general challenges and results as well as the connection between used method and results. The total flexibility is estimated to $12-23 \mathrm{GW}$ in a system with a total peak load of $77 \mathrm{GW}$.
\end{abstract}

\section{Introduction}

The world's total electric consumption is currently (2016) around 24,800 TWh per year [1] of which around $5.2 \%$ [1] is provided by Variable Renewable Energy (VRE), such as, wind and solar power. The increase in the 5 year period 2009-2014 is for solar power $+41 \%$ per year and for wind power $+17 \%$ per year [1]. In 2014 Spain covered $24 \%$ [2] of its electric energy demand with wind plus solar power. The corresponding figures were $21 \%$ for Ireland $25 \%$ for Portugal, and $45 \%$ for Denmark [2]. The impacts and integration efforts are, however, quite different for Ireland, an isolated system, and Portugal, Spain and Denmark which are part of larger electricity systems. For example Portugal, Spain and Denmark west are a part of the European continental synchronous region that has $10 \%$ wind and PV while Ireland is only asynchronously connected to UK.

For the future there is a high expectation for a continuous increase of variable renewable power. One example is the European decisions for 2020 and 2030, which means an increased target from $20 \%$ renewable energy sources (RES) for 2020 up to $27 \%$ for 2030 [3] with $29 \%$ RES in the electricity generation, potentially up to $35 \%$ [4]. With a high share of wind and solar power there will be situations with both very low availability of wind and solar as well as situations with high availability. A more detailed analysis of the challenges with a high share of wind power, including impact on adequacy, is available from [5] and its references.

The flexibility handled in this paper mainly considers the possibility to decrease demand in high load situations. This is one solution to the "adequacy" challenge. The Nordic Transmission System Operators (TSO) [6] have identified that "The share of wind power ... is expected to triple in the period 2010-2025". Concerning "Generation adequacy" it is stated: "At the moment, low market prices represent one of the main challenges for the Nordic power system. Reduced profitability of conventional power generation will lead to lower capacity of thermal and nuclear power plants." And further: "Measures to address adequacy should be identified from a Nordic perspective". A preliminary estimation of the Loss of Load Probability (LOLP) in the Nordic system, c.f.

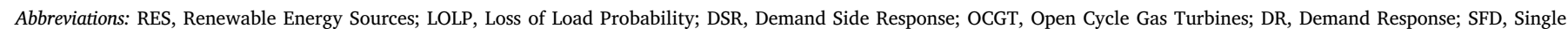

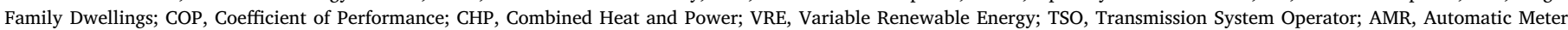

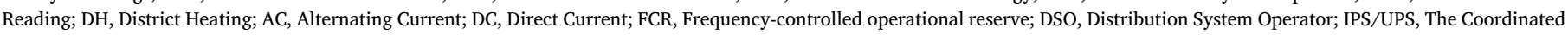
Power System consisting of Russia and 9 other countries

This paper has been written as a part of the Nordic Energy Research project Flex4RES.

* Corresponding author.

E-mail addresses: 1sod@kth.se (L. Söder), peter.lund@aalto.fi (P.D. Lund), hardi.koduvere@ttu.ee (H. Koduvere), torjus.bolkesjo@nmbu.no (T.F. Bolkesjø), geir.rossebo@nmbu.no (G.H. Rossebø), emso@dtu.dk (E. Rosenlund-Soysal), klsk@dtu.dk (K. Skytte), jokat@dtu.dk (J. Katz), dagnija.blumberga@rtu.lv (D. Blumberga). 


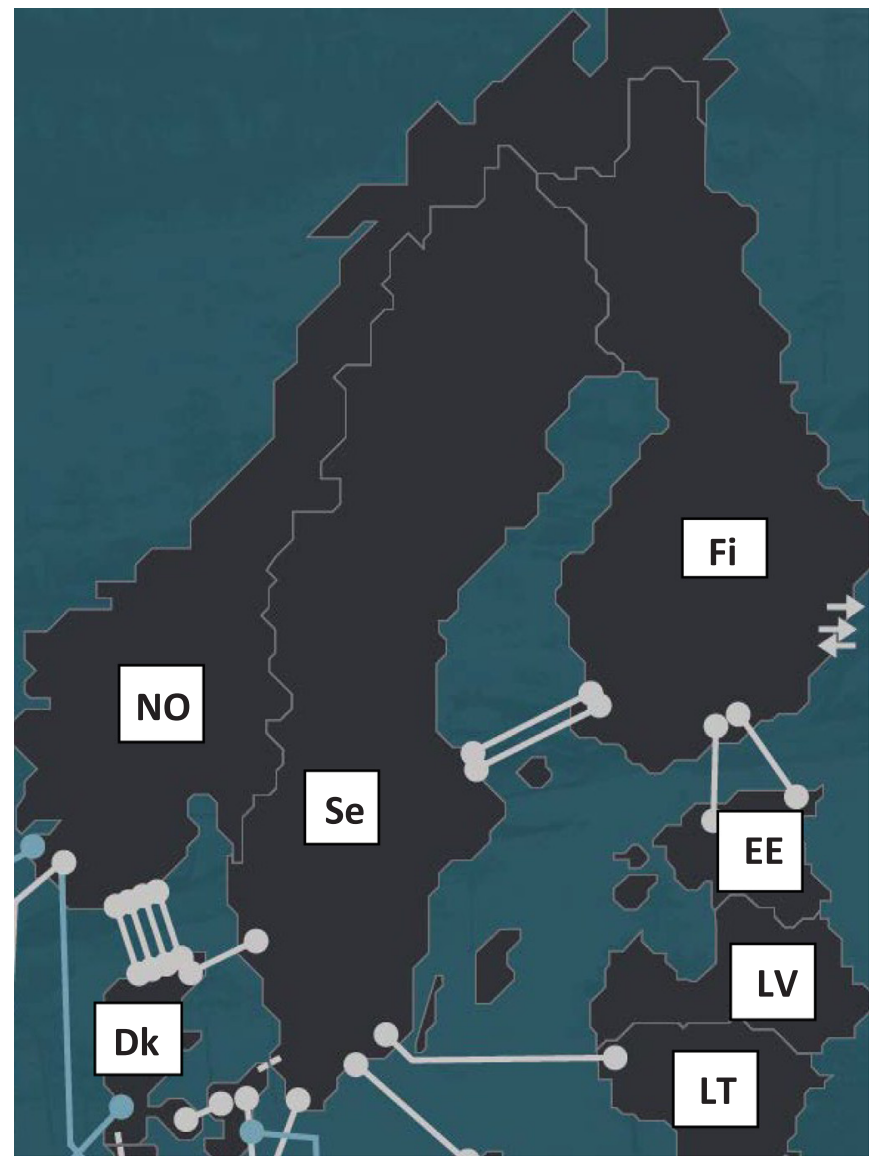

Fig. 1. Nordic power system with interconnections [6].

Fig. 1, with higher share of wind power replacing thermal production is presented in [7]. The estimation is based on a theory presented in [8]. It showed significantly higher LOLP values than today and it is stated that "possible solutions include more flexible demand". However, the key question here is the potential of flexible demand.

International Energy Agency (IEA) in its recent World Energy Outlook (2017) [9] highlights the importance of digitalization to provide better demand-side flexibility. IEA estimates that nearly $185 \mathrm{GW}$ of demand-side flexibility could be reached cost effectively by 2040. IEA also recognizes the importance of demand-side response (DSR) as a source of flexibility for the integration of variable renewable electricity (WEO 2017). Globally IEA estimates a DSR potential of nearly $4000 \mathrm{TWh} / \mathrm{yr}$, or $15 \%$ of total electricity demand. In [4] different approaches, technologies, and strategies to manage large-scale schemes of variable renewable electricity such as solar and wind power are reviewed. A specific focus in [4] was the potentials on the consumer side.

However, an important question is how large these potentials are. In general, large amounts of solar and wind power is mainly a challenge for the future, so flexible consumers are not realized to a large extent in current systems. This means that in order to design a rational future power system one has also to estimate the potential of consumer flexibility. This can be done for different consumer sectors, with different methods $[10,11]$ and for different areas, e.g. [12-14]. Here, in this paper, the results for seven different countries will be summarized concerning available flexibility in different consumer sectors.

Our study focuses on seven countries in Northern Europe to review the potential of demand side response across the different energy use sectors to better understand which factors could contribute to this potential, but also to understand the magnitude of this potential for the energy transition to clean energy. Northern Europe as a case is interesting as this region has pioneered deregulation of the electricity
Table 1

Consumption and production during 2016 in TWh from different sources in the studied countries [2].

\begin{tabular}{lllllllll}
\hline Source & Dk & EE & Fi & LT & LV & NO & Se & Tot \\
\hline Nucl. & - & - & 22,3 & - & - & - & 60,5 & 83 \\
Fossil & 10,8 & 9,0 & 13,4 & 1,1 & 2,9 & 3,1 & 3,3 & 44 \\
Hydro & - & - & 15,6 & 0,4 & 2,5 & 143 & 61,2 & 223 \\
VRE & 13,5 & 0,6 & 3,1 & 1,2 & 0,1 & 2,1 & 15,4 & 36 \\
Bio & 4,4 & 0,8 & 10,8 & 0,4 & 0,8 & - & 10,2 & 27 \\
Prod: & 28,7 & 10,4 & 66,0 & 4,0 & 6,3 & 149 & 152 & 416 \\
Cons. & 34,5 & 8,4 & 85,0 & 11,4 & 7,3 & 133 & 140 & 419 \\
\hline
\end{tabular}

markets in the 1990s and has a highly resilient common power market, and could also show the way on demand-side flexibility for managing large shares of variable renewable power. In addition to this, the ambitions for the future concerning renewable energy is significant. Denmark had in $201647 \%$ of its electric energy production from wind power, and Sweden had $40 \%$ of its yearly production from nuclear power, Table 1. But the Swedish parliament has decided: "goal in 2040 is $100 \%$ renewable electricity production" [18]. Demand Response is then seen as one of the possible solutions for an efficient way to keep the balance in the power system.

The main aim here is to study the possibility to reduce the peak in situations with high demand and lower amounts of solar and wind power. This means that the need for peak units, e.g. Open Cycle Gas Turbines (OCGT), can be reduced. These units normally use fossil fuels; so in this way the Demand Side Flexibility can reduce the CO2 emissions. In Section 2 the different studies are presented. Section 3 summarizes the different results and Section 4 provides an analysis and comparison of different results. A summary and conclusions are presented in Section 5.

\section{Performed studies for available flexibility}

This study reviews available flexibility for Sweden, Denmark, Norway, Finland, Estonia, Latvia and Lithuania. The systems are of different size, c.f. Table 1, and there are different types of demands in the different countries, e.g. different amounts of electric heating and different types of industries. This has a significant impact on the flexibility. All areas have a winter peak, and comparatively low amount of air-conditioning. Below these studies will be shortly explained. All studies use the same set-up with the following nomenclature:

S: System data and Sectors for which the flexibility has been estimated including metrics of how the level is defined.

R: Results from the study

\subsection{Sweden}

S: Sweden currently gets around $40 \%$ of its power production from nuclear power. These power plants started in the period 1972-1986. During 2015 decisions were taken to close the 4 oldest stations constructed in the 1970s. In a political agreement from May 2016, Sweden will move to a $100 \%$ renewable power system. This then means that the amount of wind and solar power will significantly increase which has led to a discussion on consumer flexibility. The total Swedish energy consumption [19] was in $2015136 \mathrm{TWh}$, divided into industry (50 TWh), households ( $40 \mathrm{TWh}$ including 30 TWh for heating), service (36 TWh) and losses (10 TWh). The peak consumption in Sweden is around 27,000 MW.

R: The flexibility potential has been estimated in several reports for different sectors. The largest potentials in Sweden are in industry and electric heating. The results are summarized in Table 2.

\subsubsection{Industry}

This sector was divided into two subsectors: 
Table 2

Estimated flexibility for DR in Sweden.

\begin{tabular}{|c|c|c|c|}
\hline \multicolumn{2}{|c|}{ Sector } & \multirow{2}{*}{$\begin{array}{l}\text { Potential flexibility in } \\
\text { Demand Response } \\
\text { [MW] }\end{array}$} & \multirow{2}{*}{$\begin{array}{l}\text { Share of peak } \\
{[\%]}\end{array}$} \\
\hline $\mathrm{Nr}$ & Type & & \\
\hline 1 & Industry & $1900-2300$ [15] & $7-8.5 \%$ \\
\hline 2 & $\begin{array}{l}\text { Homeowners with electrical } \\
\text { heating }\end{array}$ & $\begin{array}{l}2000-2400[15] \text {, up to } 5500 \\
{[16,17]}\end{array}$ & $7.4-20,4 \%$ \\
\hline 3 & Shopping centers & $40-50[15]$ & $0.15-0.19 \%$ \\
\hline 4 & Offices & $140[15]$ & $0.5 \%$ \\
\hline \multirow[t]{2}{*}{5} & Schools & $10-20[15]$ & $0.04-0.07 \%$ \\
\hline & Total & $\begin{array}{l}4000-4500[15]+3100 \\
{[16,17]}\end{array}$ & $14.8-28.1 \%$ \\
\hline
\end{tabular}

1a) High-use industrial consumers. The estimation of this sector is based on interviews from a paper from 2002 [20]. A total of 60 high-use industrial consumers were interviewed regarding interest in providing flexibility in their demand. The study used an addition to the contract between the industry and the balance responsible company. What was offered depended on the type of industry and their current contract.

The addition to the contract allowed the industry to notify the balancing company $16 \mathrm{~h}$ in advance if any flexibility in electricity demand will be available. The balancing company will then evaluate if the prices are high enough to make a reduction of the traded volume on the spot market feasible.

1a) Results: 30 of the 60 interviewed industries showed interest in contributing to flexibility in demand. The estimated flexibility in demand required high electricity prices, as high as $1.3 \mathrm{Euro} / \mathrm{kWh}$ in order to be fully utilized. A total flexibility between $1600-2000 \mathrm{MW}$ in demand was estimated for this sector.

1b) Smaller industrial consumers. This subsector is estimated from a study from 2005 [21]. Estimations of this sector are mainly based on interviews with actors/firms from different industry sectors. A new electricity contract was offered with a proposal to control the consumption at peak load hours. This contract was not advertised as a scientific project but as a proposal from the electricity retailer. The reason for this is that companies are more prone to make a bigger effort if they know that they are selected for a specific task. Price peaks of 0.3-0.5 Euro/kWh were announced to the industry in advance (hours). 300 small scale industries have the potential to contribute to the flexibility in demand in Sweden. The industries had to manually respond to high prices and withdraw consumption if possible.

1b) Results: The biggest flexibility can be achieved in industries where the production has a thermal inertia or a buffer capacity in the production. These industries are more prone to be able to reduce load for at least one hour at a minimum since it doesn't affect the production in a noticeable way. Each industry was estimated to contribute with a flexibility in demand of $1 \mathrm{MW}$. The duration of the flexibility was not clearly stated (depends what type of industry), but a time scope of 1-3 h was mentioned. The total flexibility in demand were estimated to $300 * 1 \mathrm{MW}=300 \mathrm{MW}$ for this sector.

\subsubsection{Homeowners with electrical heating}

For this sector there have been two independent studies:

2a) In [22] an estimated flexibility of 2000-2400 MW was made. The load flexibility was due to an automatization in the heating system which reacts to prices and schedules the electricity consumption/ heating accordingly. The consumers were not personally active. The case study was carried out in Vallentuna (30 km north of Stockholm) using 6 private households. Each household was equipped with a computer system that collects information from sensors measuring indoor temperatures, light intensities and electricity prices. Each house had a living area of $180 \mathrm{~m}^{2}$ and good isolation. Each house had an electrical heat pump which covered $70 \%$ of the heating with a power consumption of $10 \mathrm{~kW}$ in order to keep an indoor temperature of $21^{\circ} \mathrm{C}$ at the rated outdoor temperature, in this case $-21^{\circ} \mathrm{C}$. The households were exposed to simulated price spikes, prices going from 0.03 Euro/ $\mathrm{kWh}$ to spikes between 0.1 and 2 Euro/kWh in 5 different cases, with spike duration of $1-3 \mathrm{~h}$. The spikes were in 4 cases known to the system in advance and this made preheating possible. In one case the system was chocked without information of the spike and the heating was immediately turned off.

2a) Results: There are 1.2 million electrically heated private home dwellings in Sweden where (2013) 1.1 million homes have some sort of electrical heat pump. Each private home dwelling could provide a total flexibility of $10-15 \mathrm{kWh}$ per 24 -h period without reducing the indoor temperature noticeably for the residents. Possibility to move $2 \mathrm{~kW}$ of demand per household from one hour to the next. This yields in total $1100,000 * 2 \mathrm{~kW}=2200 \mathrm{MW}$. The error factor $( \pm 200 \mathrm{MW})$ is a rough estimation from the results in the field study.

2b) This study is based on the results presented in [16] and [17]. The study is based on an optimization routine which governs the flexibility in demand for Swedish single-family dwellings. The system reads electricity spot prices (day ahead) and corresponds with heating the single-family dwellings (SFDs) in an optimized way. There are approximately two million single-family dwellings in Sweden, out of which 1.3 million have some form of electrical heating system. The electricity demand for space heating is calculated with the buildingstock model together with an additional sub-model developed to shift space-heating loads in time. The sub-model model optimizes the electrical heating systems towards hourly day-ahead electricity spot prices from the power exchange Nordpool. The buildings are located in 30 different municipalities, chosen to represent different climatic regions and sizes of municipalities with an indoor temperature between $21.2^{\circ} \mathrm{C}$ and $24^{\circ} \mathrm{C}$. 571 sample buildings represent the Swedish SFDs with electrical heating in the study. Years 2010 and 2012 are investigated. Six different types of electrical heating systems are used with different levels of efficiency: Electric boilers; Direct electric heating; Four different types of heat pumps (Different COPs, 3.5, 3, 2.5, and 1).

2b) Results: In year 2010, Sweden had a common electricity price, with an average annual electricity price of $0.062 € / \mathrm{kWh}$ and for Year 2012 , the following average prices (in $€ / \mathrm{kWh}$ ) occurred in the four pricing areas: 0.032 (SE1), 0.032 (SE2), 0.033 (SE3), and 0.034 (SE4). The electricity tax, VAT, distribution fee, and company surcharge were set at $0.0417 € / \mathrm{kWh}, 25 \%, 0.0345 € / \mathrm{kWh}$, and $0.0046 € / \mathrm{kWh}$, respectively. Three different shifting patterns in electricity loads for the SFDs were observed as a result of the optimization.

1. Fairly flat price curve followed by an increase in electricity price: Large decrease in load for the hour with high electricity price, and a large increase in load on the hour or hours just prior to the decrease.

2. Lower priced hour is surrounded in time by hours of higher and flat prices: load from several hours being concentrated into the lowprice hour.

3. Continuously increasing price curve: result in a decrease in load during one or a few hours with the load increase being spread out during several of the preceding hours to utilize the lower prices.

In theory the total flexibility in load for all Swedish SFDs are $7.3 \mathrm{GW}$ which could be utilized for one hour. The observed results from the optimization during the high price year of 2010 showed that the maximum flexibility in load for one hour (dependent on the season) is:

$5.5 \mathrm{GWh} / \mathrm{h}$ for the winter;

- $3 \mathrm{GWh} / \mathrm{h}$ for the spring;

$1.5 \mathrm{GWh} / \mathrm{h}$ for the summer;

$4.5 \mathrm{GWh} / \mathrm{h}$ for the autumn.

\subsection{Denmark}

S: Following the energy crises of the 1970s the Danish electricity 
system has been developed towards a highly decentralized supply structure based on large shares of combined heat and power (CHP) production and wind power. By the end of 2015 the installed wind power capacity in Denmark was in total 5070 MW of which 3801 MW were placed onshore and $1269 \mathrm{MW}$ offshore [23] covering $42.1 \%$ of the domestic power consumption [24]. This makes Denmark one of the countries in the world with the largest share of VRE in electricity already today. Based on recent political agreements this development will continue, as the electricity system is supposed to become fully renewable in 2035 with substantial contributions from wind power [25]. With a large share of VRE, variability and uncertainty of production increase. At the same time, conventional thermal capacity is mothballed or decommissioned reducing flexibility on the supply side [26]. Thermal plants in 2014 covered about $45 \%$ of the consumption [27] (around $60 \%$ of it as cogeneration [28]). Due to low electricity prices and the phase-out of the subsidies for decentralized CHP by 2018, decentralized CHP capacity is expected to decline sharply to $1000 \mathrm{MW}$ [29].

The reduction in flexible generation capacity enhances the need for alternative flexibility options such as demand-side management. However, the issue of production variability in the Danish context is not limited to the question of low VRE production; over-generation is also widely debated [30]. In Denmark, flexible electricity consumption has been discussed as an option to reduce cost of electricity production, regulating power reserves and grid development, and the Danish TSO, Energinet, has estimated the socio-economic value of flexible heat pump operation and flexible charging of hybrid cars to be 6.1 Billion DKK [31]. Smart consumption, including peak load reduction, could become an important aspect of the future electricity system.

In 2013 the Danish residential sector consumed 10,291 GWh of electricity, while the commercial sector and industry consumed $10,309 \mathrm{GWh}$ and 10,222 GWh, respectively [32]. The peak consumption in Denmark was approx. $6100 \mathrm{MW}$ in 2014 [33].

R: Overall, the potential for peak load reduction in Denmark is rather under-investigated, in particular for the industry and services sectors. Here, several sources for estimating the demand-side flexibility potential in Denmark are used, including a report published by Ea Energianalyse in 2011 [34], assumptions of the Danish Market Model 2.0 [35] from 2015, and results of the research projects Ecogrid [36] from 2015. Furthermore, a study by Gils [37] provides an assessment of theoretical potentials, and Kwon \& Østergaard [38] provide estimates for the year 2050 .

While [36,37] and [35] report their results in capacity (MW), [34] gives flexibility estimates in energy terms (MWh per year). Therefore, manipulation with the estimates of [34] is needed in order to obtain a capacity estimate. [38] gives both values in capacity and energy terms. For the sake of consistency, the energy values are taken and manipulated similar to [34].

In [34] the technical demand-side flexibility potential is estimated as a percentage of the annual energy consumption of a number of appliances used by residential, industry and commercial consumers. The estimates are based on expert assessments and a number of other reports. The study stresses that the potential estimates are associated with a considerable uncertainty.

The report divides the potentials into hourly, daily and permanent flexibility. While the permanent flexibility represents a reduction of the consumption that can be permanently sustained, the hourly and daily flexibility represents load-shift within hourly and daily timeframes. The potential presented here is the sum of the three types of flexibility. This sum provides for an estimate of the potential demand-side flexibility within the narrowest timeframe, using the assumption that if load can be shifted from day to day, then it can also be shifted from hour to hour.

For an updated estimate of the potential the final consumption data of each sector has been updated according to 2013 sectorial consumption data from Danish Energy Agency [32]. The distribution of the consumption on different appliance groups (light, heating etc.) is based on the assumptions of [34].
Table 3

Estimated DR potentials in Denmark.

\begin{tabular}{|c|c|c|c|}
\hline \multicolumn{2}{|c|}{ B. Sector } & \multirow{2}{*}{$\begin{array}{l}\text { Potential flexibility in } \\
\text { demand response } \\
{[\mathrm{MW}]}\end{array}$} & \multirow{2}{*}{$\begin{array}{l}\text { Share of peak } \\
{[\%]}\end{array}$} \\
\hline $\mathrm{Nr}$ & Type & & \\
\hline 1 & Residential (excl. heating) & $\begin{array}{l}243[34]-414[37] \text { (376 in } \\
2050[38])\end{array}$ & $4-6.8$ \\
\hline 2 & $\begin{array}{l}\text { Residential water and } \\
\text { space heating }\end{array}$ & $\begin{array}{l}85[37]-100[36]-172 \\
{[34]} \\
(\text { not in } 2050[38])\end{array}$ & $1.4-2.8$ \\
\hline 3 & Commercial sector & $\begin{array}{l}60[35]-250[34]-310 \\
{[37]}\end{array}$ & $1-5.1$ \\
\hline 4 & Industry & $\begin{array}{l}16[35]-111[37]-213 \\
{[34]} \\
(674 \text { in } 2050[38])\end{array}$ & $0.3-3.5$ \\
\hline 5 & $\begin{array}{l}\text { Emergency power system } \\
\text { Total }\end{array}$ & $\begin{array}{l}300[35] \\
704-1409 \text { (up to } 1898 \text { in } \\
2050 \text { ) }\end{array}$ & $\begin{array}{l}4.9 \\
11.5-23.1(31.1)\end{array}$ \\
\hline
\end{tabular}

Furthermore, the flexibility load estimate for [34] and [38] is found by dividing the annual flexible consumption by the $8760 \mathrm{~h}$ per year. In this way, the consumption is averaged over the year, which results in a conservative estimate of the potential peak load reduction.

In [37] both load-reduction and load-increase potentials are exposed, but only the load-reduction potentials are considered. Although the assessment in [37] exposes theoretical potentials, the values obtained from that study are compared to other technical potentials, as they constitute an upper estimate.

The total potential peak-load reduction in Denmark is estimated to be 704-1409 MW, of which the residential sector constitutes the largest share (see Table 3). This results in an overall peak-shaving potential of about $12-23 \%$. According to [38], the trend will be a substantial growth until 2050, with a future peak-shaving potential of about $31 \%$. The details for estimating the load potential of each sector are briefly explained below.

\subsubsection{Residential consumers}

In [34] it was assessed that residential consumers can contribute to flexibility through automation in home appliances. Space heating and refrigerators/freezers provides the largest share of the potential loadreduction as they are expected to be able to shift $80 \%$ and $50 \%$ of their consumption, respectively. Furthermore, the usage of washing machines and dryers and pumping in central heating systems can, to some extent, be postponed to the night, and therefore also contribute to the flexibility potential. According to assessment in [34] lighting can be marginally reduced during peak hours, and home electronics can also shift the consumption slightly. However, since only automatically controlled appliances are considered flexible, consumption of electricity for cooking and television does not contribute to peak-load reduction.

In [36] the results are reported for a large-scale demand-response demonstration project offering an estimate of the flexibility potential of residential electric water and space heating. In the project, 654 houses equipped with semi-automated heat pumps and 444 houses with fully automated electric heating were exposed to real-time electricity marginal prices that consisted of day-ahead prices adjusted with the realtime balancing price. The peak-load reduction estimate for residential heating is based on observations of the optimized heater operation in the fully automated houses.

[35] does not include electric heating and argues that due to high investment costs this kind of flexibility is not expected to be activated. [38] argues that electric boilers will not be future heating sources, and flexible demand in 2050's residential sector is estimated to concern solely refrigerators/freezers and washing equipment. Since here the focus is on a technical rather than a techno-economic potential, such zero-estimates are not included here.

The assessment from [34] indicates a total flexibility potential of 
$243 \mathrm{MW}$ for residential consumers, excluding heating. The assessment from [37] is somewhat higher, which can be explained by the fact that [37] is looking at theoretical potentials, which constitute an upper bound for technical potential.

In [36] a maximum peak load reduction of $0.84 \mathrm{~kW}$ has been measured for houses heated with fully automated electric heating exposed to real time electricity prices. With approx. 120,000 houses heated with electricity in Denmark [39], around 100 MW should be available on a national basis. The estimate based on [34]'s assessment is $172 \mathrm{MW}$, which is somewhat higher. The difference may be explained by the fact that [34] has assessed the technical potential, while the estimate of [36] is the observed potential due to responses to price signals. The assessment from [37] is comparatively low. This can be explained by the fact that only heat circulation pumps are considered for residential heating in that study.

\subsubsection{Commercial}

According to [34], 60\% of the electricity consumption in the commercial sector originates from lighting and cooling/freezing, and the largest flexibility potential is to be found from these appliances. Electronics and ventilation also have a minor contribution to the flexibility potential. [35] estimates a potential for shifting electricity consumption of ventilation and cooling in office buildings and shopping malls. [35] does not consider other commercial flexibility resources. [38] estimates a future potential for cooling/freezing, ventilation, space heating as well as for pumping, assuming the installation of adequate storage tanks.

The potential load-reduction in the commercial sector is around $250 \mathrm{MW}$ according to the estimation based on [34], and around $310 \mathrm{MW}$ according to [37]. [35] estimates a potential for hour-to-hour load-reduction in commercial buildings (i.e. used for trades, services and public administration) of 190-265 MW during working hours in June through August. The potential is based on ventilation and cooling, for which demand is lower during the winter. On average, $130 \mathrm{MW}$ of load-reductions during the summer season and $60 \mathrm{MW}$ during the winter season is suggested.

\subsubsection{Industry}

While [34] assumes that primary industrial energy consumption (process energy) is unable to provide peak-load reduction, it estimates a flexibility potential from secondary energy consumption. Ventilation and cooling provides the largest potential with $30 \%$ and $50 \%$ of the electricity consumption in these groups, respectively, being able to shift from hour to hour.

[35] bases its assessment of the industrial flexibility potential on case studies of two companies, one iron foundry and one cement manufacturer. Additional flexibility potential in the sector is considered to be minimal and therefore not included. According to [35] market gardens and cold storages cannot provide additional flexibility during peak-load hours (7-20), as most of them already have agreements with suppliers about operating outside these hours.

As for the commercial sector, [38] estimates a future potential for cooling/freezing, ventilation, space heating and pumping. However, only half of the cooling/freezing and pumping demands are assumed to be able to provide flexibility.

According to [35] most of the electricity intensive industry, i.e. cement manufacturing and iron foundries, are able to contribute with $16 \mathrm{MW}$ of load-reduction in total during weekdays. The estimates based on [37] and [34] are much higher (111 and $213 \mathrm{MW}$ ), as they include the potential from a variety of appliances in the industry.

\subsubsection{Emergency power systems}

[35] considers emergency power systems a potential option for reducing the load on the grid. While technically, emergency power systems are unused production capacity, they are historically considered $s$ part of the demand side. In Denmark, hospitals, water treatment facilities, police buildings, core political institutions, and private companies have a total emergency capacity of $300 \mathrm{MW}$ at their disposal. Emergency power systems are not considered in [38], but here it is assumed that their potential will be unchanged in 2050. [35] assumes that the capacity of all emergency power systems may be used for loadreduction in the electricity system, i.e. $300 \mathrm{MW}$.

\subsection{Norway}

S: Hydro power is the dominant power technology in Norway, accounting for approximately $96 \%$ of annual power generation in a normal hydrological year. The remaining generation consists of about equal shares of wind and thermal power. The majority of the hydro resource may be stored in reservoirs implying that the hydropower system can provide large amounts of short-term flexibility. Nevertheless, the Norwegian system will to an increasing extent become integrated with the rest of the North European systems in the years to come - e.g. two $1400 \mathrm{MW}$ interconnectors will be established to Germany and United Kingdom - and demand side flexibility is hence of high interest also in Norway. The gross Norwegian electricity consumption in 2015 was 126 TWh [40], divided into industry and mining (55 TWh), Households and agriculture (39 TWh), service (26 TWh) and losses and pumping ( $9 \mathrm{TWh}$ ). The peak consumption in Norway is around 24,000 MW.

R: Flexibility potential on the demand side is rather sparsely analyzed in Norway - probably as a consequence of the large supply side flexibility available. Some recent studies address case studies for smaller areas or sectors in Norway, like [41] which analyze how large industrial consumers adapt to hourly metering, A few recent studies like [42-44] have studied short term energy consumption behavior using micro level data from smart meters while [45] review ongoing activities within demand side flexibility more in general. There are also a few studies reporting potentials for some, but not all sectors. The results from Norwegian DR potential studies are summarized in Table 4. The main DR potentials in Norway comes from the industry sector and from electric heating in households and the service sector

In [40] demand side flexibility potentials are provided for space heating and hot water for all sectors by upscaling loads originating from the Trondheim-region and applying climate data from this region as an average for the whole country. The study stresses the risk of system failure if all loads are reconnected simultaneously. In [46] the DR potentials are divided into sector groups $1-3$, only. By combing the potentials of [40] and [46] there is hence a risk that some potentials for sector groups 4-6 (from study [46]) have already been counted in sector groups 1-3 (using the estimates from [40]). Potentials are estimated based on certain assumptions regarding consumer response to high prices using national statistics as an input. Since data largely are based on energy consumption and not load, load duration for different consumer segments are used to calculate DR. The underlying data are at a macro level, and since quite strong behavioral assumptions are made,

Table 4

Estimated DR potentials in Norway.

\begin{tabular}{|c|c|c|c|}
\hline \multicolumn{2}{|c|}{ Sector } & \multirow{2}{*}{$\begin{array}{l}\text { Potential flexibility in DR } \\
\text { [MW] }\end{array}$} & \multirow{2}{*}{$\begin{array}{l}\text { Share of peak } \\
{[\%]}\end{array}$} \\
\hline No & Type & & \\
\hline 1 & Industry & $\begin{array}{l}253-539[40] \text { up to } \\
1000-1500[46]\end{array}$ & $1.1-6.3$ \\
\hline 2 & $\begin{array}{l}\text { Homeowners with } \\
\text { electrical heating }\end{array}$ & $\begin{array}{l}1000-1500[46,47] \text { and up to } \\
1926-2744[40]\end{array}$ & $4.2-11.4$ \\
\hline 3 & $\begin{array}{l}\text { Offices and commercial } \\
\text { buildings }\end{array}$ & $457-970[40,46]$ & $1.9-4$ \\
\hline 4 & Hospitals and healthcare & $71-150[40]$ & $0.3-0.6$ \\
\hline 5 & Schools & $147-310[40]$ & $0.6-1.3$ \\
\hline \multirow[t]{2}{*}{6} & Other & $100-300[40]$ and 238 [46] & $0.4-1.3$ \\
\hline & Total & & $8.5-24.9$ \\
\hline
\end{tabular}


the estimated potentials should be regarded highly uncertain. Another approach is found in [47] where 40 residential customers had hourly metering equipment (AMR) installed and they were monitored over one year. Customers were presented for real-time prices and their observed behavior was used to estimate a potential for demand response in households on a national scale. The study points out that the study sample consisted of a low number of observations, that they were from the same geographic area and that the sample consisted of consumers interested in the matter. These data sampling issues imply that one should be careful when generalizing the results.

\subsubsection{Industry}

The potential for DR in the Norwegian industry is estimated to be in the range 253-539 MW, for $120 \mathrm{~min}$ and $15 \mathrm{~min}$ respectively [40]. The estimates hold for an outdoor temp of $-10^{\circ} \mathrm{C}$, and time period 8 A.M.4 P.M. The study reported in [46] used a statistical approach and estimated DR potentials of $1000-1500 \mathrm{MW}$ for the industry. The large difference between the two studies is probably due to different methods used and different system boundaries. In [40] the potential arise from examined entities, with empathies on space and water heating while [46] also includes industrial processes.

\subsubsection{Home owners with electrical heating}

For DR in households two different consumption segments are considered: Space-heating and hydronic-heating systems. [46] estimates the potential DR to be roughly 1000-1500 MW in total. In [47] the potential DR from water-heaters is $1000 \mathrm{MW}$. In [40] space heating flexibility is reported in the range $1186 \mathrm{MW}$ (over $60 \mathrm{~min}$ )-1694 MW (less than $60 \mathrm{~min}$ ), and the potential in hydronic-heating systems is estimated to be $740 \mathrm{MW}$ during daytime, and $880-1050 \mathrm{MW}$ for morning and evening peak time, respectively.

\subsubsection{Offices and commercial buildings}

The flexibility potential in this category is in [40] estimated to be in the range $457-970 \mathrm{MW}$, for $120 \mathrm{~min}$ and $15 \mathrm{~min}$ respectively. The estimate holds for an outdoor temp of $-10^{\circ} \mathrm{C}$, and time period 8 a.m. -4 p.m.

In [46] this potential is estimated to $500-1000 \mathrm{MW}$

\subsubsection{Hospitals and healthcare}

The flexibility potential in hospitals and other health care buildings is estimated to be in the range $71-150 \mathrm{MW}$, for $120 \mathrm{~min}$ and $15 \mathrm{~min}$ respectively [40]. The estimate holds for an outdoor temp $-10{ }^{\circ} \mathrm{C}$, and time period 8 A.M.-4 P.M.

\subsubsection{Schools}

This category is estimated to be in the range 147-310 MW, for $120 \mathrm{~min}$ and $15 \mathrm{~min}$ respectively [40]. The estimate holds for an outdoor temp -10C, and time period 8 a.m. -4 p.m.

\subsubsection{Other}

DR in District heating (DH) is set to $238 \mathrm{MW}$ (Annually duration: $2100 \mathrm{~h})$ in [46].

\subsection{Finland}

S: Finland has one of the most versatile power systems in the Nordic region, when viewed by power sources. In 2015, the total electricity demand was $82.5 \mathrm{TWh}$, of which $20 \%$ was covered by hydropower, $27 \%$ nuclear, $25 \%$ CHP, $5 \%$ by condensing power plants, respectively [48]. Almost $20 \%$ of the electricity was imported from the Nordpool Electricity Exchange and from Russia. The high share of imported power is a major concern, as this would also reduce the flexibility options, if cross-boundary power transmission becomes overloaded. $45 \%$ of the domestic power production is based on renewable energy and close to $80 \%$ of all power produced is carbon-free. A special feature of
Table 5

Flexibility potential in Finland through the transmission operator Fingrid [49].

\begin{tabular}{lll}
\hline Type of demand flexibility & min MW & max MW \\
\hline E-spot day-ahead market & 200 & 600 \\
Elbas intra-day market & 0 & 200 \\
Regulation market FRR-M & 100 & 300 \\
Regulation capacity market (New market upcoming in & 0 & 0 \\
2016) & 10 & 10 \\
Reserve power & 0 & 0 \\
Automatic frequency control FRR-A & 0.2 & 0.2 \\
Frequency-controlled operational reserve FCR-N & 100 & 100 \\
Frequency-controlled malfunction reserve FCR-D & 410.2 & 1210.2 \\
TOTAL & & \\
\hline
\end{tabular}

the Finnish electricity demand is the high share of the industrial use, which is $47 \%$ of all electricity. Households stand for $27 \%$, services $23 \%$, and losses $3 \%$, respectively. The peak power demand is $15,105 \mathrm{MW}$ (7 Jan 2016). Due to deficit in own power production capacity, mainly because of the long delay of the nuclear power plant under construction in Olkiluoto (1600 MW), the power system is highly stressed during the peak, which also emphasis the importance of supply and demand flexibility. Finland is well connected to neighboring countries through major transmission capacity: to Sweden (2200 MW), Estonia (1000 MW), Russia (1400 MW), and Norway (100 MW) [49].

R: Extensive analyses on the flexibility potential in Finland from the demand response point of view have not been done, except for some sectoral analyses. The Finnish transmission operator Fingrid Ltd. is responsible for the grid functionality and provides demand response through the existing market mechanisms. Fingrid's estimate for flexibility is given in Table 5 [49] and it could be considered as the existing flexibility reserve based on DR in Finland for the moment.

The market-based flexibility estimate by Fingrid corresponds to $2.7-8.0 \%$ of the peak demand. This potential is in immediate use. The technical potential of DR flexibility is, however, much larger, but the estimates include larger uncertainties than in Table 5. These estimates are here compiled in Table 6. The numbers are not fully additive for which reason the sum of these doesn't equal the total DR potential estimate

The DR potentials in Table 5 have been assessed in different ways. A summary of the approaches is given in the next.

\subsubsection{Industry}

Industries often represent a constant base load in Finland, in particular energy-intensive industrial loads, which dominate the industrysector energy use. These loads are large and centralized, and readily manageable by system operators. The estimates for the technical potential of DR in industrial loads are from [50]: grinderies in pulp and paper industry correspond to $6 \%$ of the total peak; electrolysis, electric arc furnaces and rolling mills in metal industry $2 \%$; electrolysers, extruders, and compressors in chemical industry $1 \%$; and mills in cement, lime and gypsum production $0.04 \%$. Some of the above flexibility has already been contracted as disturbance reserve to the transmission

Table 6

Crude estimate of DR based flexibility potential in Finland.

\begin{tabular}{lll}
\hline Sector & $\begin{array}{l}\text { Potential flexibility in DR } \\
\text { [MW] }\end{array}$ & $\begin{array}{l}\text { \% of peak } \\
\text { demand }\end{array}$ \\
\hline $\begin{array}{l}\text { Industry [50] } \\
\begin{array}{l}\text { Households with electrical } \\
\text { heating [51,52] }\end{array}\end{array}$ & 1360 & 9 \\
$\begin{array}{l}\text { Households wet and cold } \\
\quad \text { appliances [52,53] }\end{array}$ & 392 & $7.6-9.6$ \\
$\begin{array}{l}\text { Service sector [54,55] } \\
\text { Winter peak [51,52] }\end{array}$ & 1500 & 2.6 \\
TOTAL & $3474-4380$ & 10 \\
& 4500 & $23-29$
\end{tabular}


system operator (TSO) and is included in Table 5. For industries, the DR impose a challenge as industrial processes need to be run on a continuous basis.

\subsubsection{Households}

The total peak-shaving gross potential in the winter is estimated to be $23-29 \%$ of the peak demand $[51,52]$. Considering electrically heated buildings only with a peak demand of around 5000 MW (620,000 housing units), the peak-shaving DSM potential could be 1,150$1450 \mathrm{MW}$. Wet and cold appliances could contribute an additional $2.6 \%$ [51-53].

\subsubsection{Services}

Very crude estimates only are available based on estimates/measurements in Helsinki [54], which are aggregated here to the whole country. E.g. grocery store refrigeration and freezer warehouses could shave ca $10 \%$ of the total peak. The time that these loads can shift their consumption ranges from 1 to $25 \mathrm{~h}$, depending on the controlled power and state of the devices freezer warehouses are shiftable for max. $4 \mathrm{~h}$ $[54,55]$.

\subsubsection{Other}

Not estimated in Table 5, there are large residential point/peak loads that could be used in the future for DR. For instance, car preheating electric systems represent a total nominal load $800 \mathrm{MW}$ and residential electric saunas amazing $9000 \mathrm{MW}$ [55].

\subsection{Estonia}

S: The generation side of the power system in Estonia is dominated by conventional condensing power plants, which use oil shale as fuel. The oil shale power plants have been historically providing roughly $85-90 \%$ of the total produced power in Estonia. As of 2016, the installed capacity of oil shale power plants exceeds the peak load by roughly $400 \mathrm{MW}$ [56]. Other significant sources of power are wind turbines and biomass-burning cogeneration power plants [57]. In addition to the high installed capacity, Estonian power system is extremely well interconnected with neighboring systems, with a total of 1000 MW of DC connections to Finland and 800 MW of AC connections to Latvia. Interconnections also exist to Russia, which are not used for commercial purposes, but are utilized for balancing and frequency control $[33,58]$. The annual electrical energy consumption is around $8 \mathrm{TWh}$ with a peak load of about $1550 \mathrm{MW}$ and the demand is expected to increase steadily [56]. In 2016 the overall demand, about 2.4 TWh is consumed by industry and $1.9 \mathrm{TWh}$ in households [57]. Electrical heating is playing a decreasing role in the overall electricity consumption in private households. The largest DSO, Elektrilevi, has done an estimation by observing demand changes in different outside temperature situations, which puts the amount of electric power used for heating purposes around 800 GWh [59].

The oil shale power plants along with the interconnection capacities have so far been adequate to provide flexibility to the system; however, their role in the Estonian power system can be seen decreasing in the future. This is due to increasingly strict environmental regulations, amortization of older oil shale power plants as well as using more oil shale for oil production instead of condensing power plants [56]. Although condensing oil shale power plants will hardly be fully phased out in the near future, it is necessary to look new sources of flexibility to compliment biomass cogeneration power plants and the increasing share of wind power. Furthermore, the need for flexibility services in the Baltic countries may increase drastically when they are decoupled from the IPS/UPS system [60]. The first studies regarding the decoupling have already been finalized and synchronous operation of the Baltic power systems with the Central European system has been found feasible in the future [61].

Consumer side flexibility has not been widely researched in Estonia, with just a handful of analysis available. Only one report has been presented, which has aimed to give a numerical value for the overall demand-side flexibility in Estonia [59]. The method used in the analysis was to assess the overall demand response potential in each of the consumer categories is similar. An in-depth analysis of a sample consumer was made in each of the category in order to map all the possible sources of flexibility for that consumer. Then, a generalization was made to fit the findings in individual consumers for the entire country. The angle of approach for each of the sectors is presented below, and an overall demand flexibility table is presented at the end to summarize the findings.

\subsubsection{Industry}

In industry, the paper and wood processing plants were studied in detail, as the most prominent of industrial power consumers in Estonia. Of the annual industrial power consumption, wood and paper industries constitute roughly one third of the annual industrial power consumption. A sample wood processing plant was investigated, mapping the different process stages and intermediate warehouses in great detail. It was determined how much flexibility each of the sub process could provide and for what kind of time period. This was done taking into account the processing power of other related sub processes, the capacity of intermediate storages and the aim to keep the plant at maximum production output in the long period. After concluding the analysis of the processes in a single plant, the overall power consumption of paper and wood industry in Estonia as a whole and a generalization was made. The estimate for the overall demand side flexibility in the industrial sector was estimated to be $65 \mathrm{MW}$. The forest industry in Estonia is, as of 2017, looking to invest in additional wood processing capacities, most likely increasing the number even further by 2022 [62].

\subsubsection{Homeowners with electrical heating}

In private households, individual household appliances were investigated in terms of their ability to provide flexibility services. Assumptions were made for the electrical consumption power of the devices and the number of devices in residential homes was found from statistical sources. The following appliances were found to be able to act flexibly: water heating boiler, electric heater, heat pump, deep freeze, dishwasher and the washing machine. An analysis was performed taking into consideration the consumption power of the devices as well as the spatial distribution of the consumption. An overall estimation for the whole country was made, taking into account the total power demand in the residential houses. The resulting value for demand side flexibility in residential houses is between 56.2 and $228 \mathrm{MW}$, depending on what share of the devices are consuming simultaneously. Considering the increasing overall increasing trends in household power consumption, countered by stricter energy efficiency requirements, the overall demand side flexibility of households should be quite stable in the near future.

\subsubsection{Shopping centers}

In shopping centers, two sources of flexibility were investigated: the ventilation system and deep freezes. Ventilation is able to provide flexibility for a short period during daytime, when switching the system off for a short time is feasible. Deep freezers are able to act more flexibly, but require an investment in cold storage. The investment in storage can be scaled up to provide the needed amount of flexibility. The total consumption of shopping centers was taken into account to estimate the overall aggregated power flexibility in Estonia in this particular sector. The total estimated demand side management potential in shopping malls was $26 \mathrm{MW}$

\subsubsection{Office buildings}

Two different example office buildings have been analyzed to give an estimate of power flexibility in similar buildings across the country. 
Table 7

A rough estimation of the total potential of DR in Estonia [59].

\begin{tabular}{lll}
\hline Sector & $\begin{array}{l}\text { Potential flexibility in DR } \\
{[\mathrm{MW}]}\end{array}$ & $\begin{array}{l}\text { Share of peak load } \\
(\%)\end{array}$ \\
\hline $\begin{array}{l}\text { Industry } \\
\begin{array}{l}\text { Homeowners with electrical } \\
\quad \text { heating }\end{array}\end{array}$ & 65 & 4 \\
$\begin{array}{l}\text { Shopping centers } \\
\text { Offices }\end{array}$ & $56-228$ & $4-15$ \\
Total & 26 & 2 \\
& 86 & 6 \\
\hline
\end{tabular}

One of the buildings was a standard $8 / 5$ type, where work would usually be done $8 \mathrm{~h}$ per day, 5 days per week. The second one was a 24/ 7 type of building, where work was done in shifts and continuously throughout the week. In both types of office buildings, similar sources of demand flexibility were found: ventilation, electric heating and kitchen appliances. Again, the resulting numbers were used to give an overall estimation of demand flexibility in office buildings throughout Estonia. The study shows that the demand side response potential is $72 \mathrm{MW}$ in the $8 / 5$ type buildings and $14 \mathrm{MW}$ in the 24/7 type buildings, adding up to a total of $86 \mathrm{MW}$.

R: The resulting numbers per sector and their overall share of the peak load are shown in Table 7: A rough estimation of the total potential of DR in Estonia.

The results indicate, that largest potential of demand side flexibility in Estonia is offered from private households, while shopping centers contribute the least. It should be noted that the assumed flexibility potential depends significantly on the time of use of the appliances contributing to the overall consumption at a given time. In the near future, the demand side flexibility in Estonia is expected to increase somewhat due to new investments in wood and paper industry. The change of flexibility potential in other sectors is expected to either be stable or difficult to predict.

\subsection{Latvia}

S. Latvia has set the highest mid-term renewable energy targets of all three Baltic States. According to the National Renewable energy action plan [63] Latvia's RES target for 2020 is to reach at least $59.8 \%$ share of renewable energy in total gross final electricity consumption. Electricity consumption in Latvia was $6482 \mathrm{GWh}$ in 2016, which is $0.33 \%$ increase compared to 2015 level. Electricity consumption in Latvia is expected to increase by $28-48 \%$ by 2020 compared to the base year (2005) reaching 8680-10,000 GWh

The most significant RES in Latvia historically been hydropower, but there also is potential for biomass, biogas and wind. Despite the significant share of renewables in electricity generation $31.3 \%$ in 2016) Latvian energy sector is highly dependent on imported natural gas resources. In 2016, $26.4 \%$ of gross electricity generation took place in large natural gas cogeneration plants. Latvia also uses technology specific feed-in tariff to promote electricity production from renewable energy sources [64].

Solar electricity is also used in Latvia. However, its contribution to the energy balance is minimal. According to the data of the Solar Energy Association the capacity of solar energy installed in Latvia in 2014 is the following: solar power stations connected to electricity grid - approx. 1 MWp.

The main electricity producer, electrical utility Latvenergo AS, produced $42.3 \%$ of all power in 2016. In 2016, the total installed capacity of CHP in Latvia was $1292 \mathrm{MW}$. Of this total, hydropower plants had an installed capacity of $1565 \mathrm{MW}$, while combustible fuels power plants contributed $1291 \mathrm{MW}$. The peak load was $2857 \mathrm{MW}$ and electricity consumption increased by $0,33 \%$, to $6.48 \mathrm{TWh}$.

In November 2012, the electricity market for industrial users was fully liberalized. Latvia joined the regional Scandinavian - Baltic Nord
Table 8

Estimated flexibility for DR in Latvia.

\begin{tabular}{lll}
\hline Sector & Potential flexibility in DR [MW] & Share of peak load (\%) \\
\hline Industry & $7-13$ & 1 \\
Residential & 0 & 0 \\
Tertiary & $63-70$ & $3-4$ \\
Total & $70-83$ & 5 \\
\hline
\end{tabular}

Pool Spot market for electricity contracting in June 2013. However, performance was not as good as anticipated. The interconnector with Estonia was often congested, contributing to price spikes in the Latvian/ Lithuanian price area.

Consumer side flexibility has not been widely researched in Latvia. Only few research report with general analysis are available. The methodology used to assess the DR potentials in Table 8 differs from sector to sector and assumptions, which include several aspects: only theoretical potential of DR measures is considered; load shifting are considered as DR measures; load profiles are based on literature review; annual electricity demands are assumed for the calculations of flexible load profiles; using energy for heating and/or cooling energy consumption is corrected using outside air temperature for calculating daily average temperature, temperature profiles and daily heating and cooling degree days. Calculations are based on both EU country report data published in [65] and research results presented by H.C.Gils [37]. Electricity consumption for heating in residential sector is negligible: 0.2-0.3 TWh/year. It means that flexibility for this part becomes negligible too.

\section{R. Results}

The resulting numbers per sector and their overall share of the peak load has been shown in Table 8.

The potential peak-load reduction in Latvia is estimated to be 70-83 MW, of which the residential sector constitutes the largest share. This results in an overall peak-shaving potential of $5 \%$.

\subsubsection{Industry}

The results show that industry is not the main contributor in the demand response in Latvia. The projected, theoretical demand response for industrial sector can be in the margins of 7-13 MW.

\subsubsection{Residential sector}

The obtained results from [37] show that residential sector is the biggest player in the demand response. In the case of potential load reduction residential sector would account for close to half of demand response potential, while in the case potential load increase residential sector would account for more than $90 \%$. The expected margins of demand response in residential sector were estimated to 84-737 MW.

However, according to a number of smart metering studies [66], delivery of feedback information on actual consumption can change the behavior of household customers and reduce consumption in the future. The potential energy savings could reduce share of peak load-average with $8.6 \%$ for a median extrapolating (smart metering pilot project data) to all households of Latvia [67]. Electricity consumption for heating in residential sector is negligible: $0.3-0.4 \mathrm{TWh} /$ year. It means that flexibility for this part becomes negligible too.

\subsubsection{Tertiary sector}

Tertiary sector shows the second biggest potential after the residential sector. In the case of load reduction tertiary sector account for around $30-40 \%$ of the potential demand response. While in the case load increased the meaning of the tertiary sector is dismissed due to the vast expansion of residential load. The projected, theoretical demand response for tertiary sector can be in the margins of 63-70 MW. 


\subsection{Lithuania}

By the end of 2009 around $70 \%$ of the total domestic electricity production in Lithuania was generated by the Ignalina nuclear power plant. The situation changed significantly after the disconnection of the second reactor at the Ignalina power plant in 2010. From energy exporting country, Lithuania has turned into the European Union Member State most dependent on electricity supply from abroad. Annual electricity consumption in Lithuania amounted to $11,600 \mathrm{GWh}$ in 2012 and is expected to increase by $21-22 \%$ (compared to the base year, 2005) reaching $13,875-14,000 \mathrm{GWh}$ in 2020 . Along with the electricity imports, the natural gas dominates in the electricity mix of Lithuania with a share of $55 \%$.

Lithuania has set an aim to increase the electricity produced from RES to $21 \%$ in 2020 (compared to $4.9 \%$ in 2008) in total electricity consumption [68]. Lithuania's greatest renewable energy potential is associated with the use of biofuel (both biogas, and solid biomass) and generation of onshore wind energy. In Lithuania feed-in tariffs for specific technologies are used as promotion tool for electricity production from RES [64].

In 2012, the total power generation was $5043 \mathrm{GWh}$, the largest part of it was derived from natural gas (63\%). The major change in power generation occurred in 2010, when Ignalina Nuclear Power Plant was decommissioned and power generation in the country dropped by $63 \%$. As a result Lithuania became dependent on electricity imports (in 2012 electricity import was $169.8 \%$ higher than gross domestic production). In 2012 Lithuania's electricity demand increased by $5.9 \%$ in comparison to the 2011 level.

Consumer side flexibility has not been widely researched in Lithuania. Only few researches with general analysis is available. The methodology used to assess the DR potentials in Table 9 differs from sector to sector and assumptions, which include several aspects: only theoretical potential of DR measures is considered; load shifting is considered as DR measures; load profiles are based on literature review; annual electricity demands are assumed for the calculations of flexible load profiles; using energy for heating and/or cooling energy consumption is corrected using outside air temperature for calculating daily average temperature, temperature profiles and daily heating and cooling degree days. Calculations are based on both EU country report data published in [65] and research results presented by H.C.Gils [37].

\section{R. Result}

The resulting numbers per sector and their overall share of the peak load has been shown in Table 9.

The potential peak-load reduction in Lithuania is estimated to be 77-100 MW. This result in an overall peak-shaving potential are in wide range of $6 \%$.

\subsubsection{Industry}

The results show that industry is not the main contributor in the demand response in Lithuania. The projected, theoretical demand response for industrial sector can be in the margins of 5-18 MW.

\subsubsection{Residential sector}

The obtained results in [37] show that residential sector is the

Table 9

Estimated flexibility for DR in Lithuania.

\begin{tabular}{lll}
\hline Sector & Potential flexibility in DR [MW] & Share of peak load (\%) \\
\hline Industry & $5-18$ & 1 \\
Residential & 0 & 0 \\
Tertiary & $72-82$ & 5 \\
Total & $77-100$ & 6 \\
\hline
\end{tabular}

biggest player in the demand side response. In the case of potential load reduction residential sector would account for close to half of demand response potential, while in the case potential load increase residential sector would account for more than $90 \%$. The expected margins of demand response in residential sector are 143-1034 MW.

However, this level is here not considered realistic because of lack of technical systems to make it possible to implement. So here this potential is assumed to be negligible.

\subsubsection{Tertiary sector}

Tertiary sector presents the second biggest potential after the residential sector in [37]. In the case of load reduction tertiary sector account for around $30-40 \%$ of the potential demand response. While in the case load increased the meaning of the tertiary sector is dismissed due to the vast expansion of residential load. The projected, theoretical demand response for tertiary sector can be in the margins of 72-82 MW.

\section{Summary and conclusions}

Now the results from the different studies will be summarized in order to identify possible general conclusions, at least from these studies. The results from the different studies are summarized in Table 10. Here the data is changed to percentages since the different countries have different sizes. The results in the table show:

1. The total flexibility is $15-29 \%$ of the peak, i.e. $12-23 \mathrm{GW}$. In [69] the DR potential for Germany is estimated as "Results show that DR can economically substitute up to $10 \mathrm{GW}$ of power plants". This corresponds to around $12 \%$ of the peak. For Europe [70] a study gave as result: “... total DR potential in Europe amounts $52.35 \mathrm{GW}$, This figure represents $9.4 \%$ of the peak load estimated by ENTSO-E for its 34 represented countries". The figures here are higher which probably depends on that it is "technical potential" (not "economical" as in [69], and that there is a comparatively high share of flexible heat load and industries in the Nordic countries.

2. The industries flexibility is higher in countries with higher share of industry consumption, such as Sweden, Finland and Norway. These countries have a higher share of forestry and metal processing industry which have a comparatively high possibility for flexibility.

3. Household contribution to flexibility is high in countries with high share of electric heating or heat pumps, such as Sweden, Finland and Norway.

4. A general remark is that there is really a quite large technical potential for demand side flexibility in the Nordic countries, especially Norway and Sweden. Norway and Sweden do at the same time have lot of flexible hydro power and they are maybe the two countries with the least need for short term demand side flexibility. So there will not be very strong incentives for DR in their respective countries, while it may be optimal to utilize some of this potential from a broader North European perspective. Power market integration will then be important as well as regional flexibility policies are also important, as opposed to country-wise flexibility policies.

5. The comparison shows a large variation in the obtained estimates both within and between countries. This is the result of differences in estimation method. Particularly, as the Nordic countries have a common electricity market, viewing DR just from a national perspective may be suboptimal, but viewing the DR potential in the whole Nordic context would yield a better overall use of the resource, also in terms of cost-effectiveness. This would, however, necessitate introducing new market mechanisms and updating national regulation and legislation.

6. The 'other flexibility share of peak' in Table 9 varies a lot from the country to country. The reason for this is that in some countries the potential is assessed in detail whereas in some other countries the number given here reflects more an overall technical potential. 
Table 10

Summary of flexibility potentials in seven countries.

\begin{tabular}{|c|c|c|c|c|c|c|c|c|}
\hline Country & Sweden & Denmark & Norway & Finland & Estonia & Latvia & Lithuania & Total: \\
\hline Utilization time [h] & 5037 & 5053 & 5250 & 5462 & 5161 & 5482 & 5273 & 5204 \\
\hline Peak [MW] & 27,000 & 6100 & 24,000 & 15,105 & 1550 & 1368 & 2200 & 77,323 \\
\hline Industry energy \% & $36.8 \%$ & $33.1 \%$ & $43.7 \%$ & $47.0 \%$ & $32.0 \%$ & $28.0 \%$ & $40.0 \%$ & $40.6 \%$ \\
\hline Industry flexibility, share of peak & $7.0-8.5 \%$ & $0.3-3.5 \%$ & $1.1-6.3 \%$ & $9.0 \%$ & $4.2 \%$ & $0.5-1.0 \%$ & $0.2-0.8 \%$ & $4.7-7.1 \%$ \\
\hline Household heating energy \% & $22.1 \%$ & $6.1 \%$ & $36.1 \%$ & $15.8 \%$ & $10.0 \%$ & $2.0 \%$ & $2.8 \%$ & $22.8 \%$ \\
\hline Household heating share of peak & $7.4-20.4 \%$ & $1.4-2.8 \%$ & $4.2-11.4 \%$ & $7.6-9.6 \%$ & $3.6-14.7 \%$ & $0.0 \%$ & $0.0 \%$ & $5.6-13.1 \%$ \\
\hline Other Flexibility share of peak & $0.7-0.8 \%$ & $9.9-23.1 \%$ & $3.2-7.2 \%$ & $12.5 \%$ & $7.2 \%$ & $4.6-5.1 \%$ & $3.3-3.7 \%$ & $5.1-9.4 \%$ \\
\hline Total: Share of peak & $15.2-29.7 \%$ & $11.5-29.4 \%$ & $8.5-24.9 \%$ & $29.1-31.1 \%$ & $15.0-26.1 \%$ & $5.1-6.1 \%$ & $3.5-4.6 \%$ & $15.3-29.5 \%$ \\
\hline
\end{tabular}

\section{Acknowledgements}

This paper has been written as a part of the project "Flex4RES Flex4RES - Flexibility for Variable Renewable Energy Integration". Nordic Energy Research is then acknowledged for the funding of this project under Grant no 76084.

\section{References}

[1] "BP Statistical Review," [Online]; 2017. Available: 〈https://www.bp.com/en/ global/corporate/energy-economics/statistical-review-of-world-energy.html $\rangle$. [Accessed 27 November 2017].

[2] "ENTSO-E Data portal," [Online]. Available: 〈http://www.bp.com/en/global/ corporate/about-bp/energy-economics/statistical-review-of-world-energy.html $\rangle$. [Accessed 23 July 2015].

[3] "A policy framework for climate and energy in the period from 2020 to 2030,". [Online]; 2015. Available: 〈http://eur-lex.europa.eu/legal-content/EN/TXT/?Uri = CELEX:52014DC0015〉. [Accessed 03 March 2016].

[4] European Parliament, "MEPs set ambitious targets for cleaner, more efficient energy use," 17 01. [Online]; 2018. Available: 〈http://www.europarl.europa.eu/news/en/ press-room/20180112IPR91629/meps-set-ambitious-targets-for-cleaner-moreefficient-energy-use $>$. [Accessed 05 March 2018].

[5] Holttinen. and e. al., "Design and operation of power systems with large amounts of wind power. Final summary report, IEA WIND Task 25, Phase three 2012-2014,". [Online]; 2015. Available: 〈https://community.ieawind.org/HigherLogic/System/ DownloadDocumentFile.ashx?DocumentFileKey = 87ada8ed-5a95-20bd-2bd85174e6e065d6\&forceDialog $=0\rangle$. [Accessed 01 March 2018].

[6] Statnett; Fingrid; Energinet.dk; Svenska Kraftnät, "Challenges and Opportunities for the Nordic Power System," 2016. [Online]. Available: 〈http://www.statnett.no/ Global/Dokumenter/Challenges\%20and\%20opportunities_Report.pdf $\rangle$. [Accessed 01 March 2018].

[7] Terrier V. "North European Power Systems Reliability,". [Online]; 2017. Available: $\langle$ http://kth.diva-portal.org/smash/record.jsf?Pid = diva2\%3A1077673\&dswid = 9927>. [Accessed 01 March 2018].

[8] Tomasson E, Söder L. Generation adequacy analysis of multi-area power systems with a high share of wind power. IEEE Trans Power Syst 2017(99). [1-1].

[9] International Energy Agency (IEA). "WorldEnergy Outlook," IEA. [Online]; 2017. Available: 〈https://www.iea.org/weo2017/〉. [Accessed 27 November 2017].

[10] Meyabadi AF, Deihimi M. A review of demand-side management: reconsidering theoretical framework. Renew Sustain Energy Rev 2017;80:367-79.

[11] Esther BP, Kumar KS. A survey on residential demand side management architecture, approaches, optimization models and methods. Renew Sustain Energy Rev 2016;59:342-51.

[12] Ming Z, Li S, Yanying H. Status, challenges and countermeasures of demand-side management development in China. Renew Sustain Energy Rev 2015;47:284-94.

[13] Warren P. A review of demand-side management policy in the UK. Renew Sustain Energy Rev 2017;73:966-82.

[14] Harish V, Kumar A. Demand side management in India: action plan, policies and regulations. Renew Sustain Energy Rev 2014;33:613-24.

[15] NEPP - North European Power Perspectives, "Electric Power Consumption in Sweden (in Swedish)," December. [Online]; 2015. Available: 〈http://nepp.se/pdf/ 20_resultat_elanv.pdf $>$. [Accessed 22 June 2016].

[16] Nyholm E. "Demand response and distributed solar generation in the Swedish residential sector - A techno-economic evaluation: Licentiate thesis,"October. [Online]; 2015. Available: 〈http://publications.lib.chalmers.se/records/fulltext/ 224094/224094.pdf $>$. [Accessed June 2016].

[17] Nyholm E, Puranik S, Mata E, Odenberger M, Johnsson F. Demand response potential of electrical space heating in Swedish single-family dwellings. Build Environ 2016;96:270-82.

[18] "English translation of the Swedish energy policy agreement of 10 June," 1006 2016. [Online]; 2016. Available: 〈http://www.analys.se/publikationer/rapporter/ english-translation-of-the-swedish-energy-policy-agreement-of-10-june-2016/〉. [Accessed 27 November 2017].

[19] Svensk Energi. "Electric year \& activities (in Swedish),"June 2016. [Online]; 2015. Available: 〈http://www.svenskenergi.se/Global/Statistik/El\%C3\%A5ret/el \%C3\%A5ret2015_160429_web2.pdf $\rangle$. [Accessed 22 June 2016].

[20] Kraftnät Svenska. "Industrial bids - report to power balance investigation (in
Swedish)," October. [Online]; 2002. Available: 〈http://www.svk.se/siteassets/omoss/rapporter/industribud_okt_02.pdf $\rangle$. [Accessed 22 June 2016].

[21] Lindskoug S. "Demonstration project - Power control on consumer side at capacity deficit situations, Elforsk reort 05:31 (in Swedish)," October. [Online]; 2005. Available: 〈http://www.elforsk.se/Rapporter/?Download = report\&rid=05_31_〉. [Accessed 22 June 2016].

[22] Persson E, Berg B, Fernlund F, Lindbom O. "Pilot study concerning businessmodels for consumer flexibility och self learning forcast control of consumer adapted power control - Elforsk report 12:48 (in Swedish)," June. [Online]; 2012. Available: $\left\langle\right.$ http://www.elforsk.se/Rapporter/?Download $=$ report\&rid $\left.=12_{-} 48_{-}\right\rangle$. [Accessed 22 June 2016].

[23] "Dansk Vindmølleforening. Status for wind power expansion in Danmark (in Danish).,". [Online]; 2016. Available: 〈http://www.dkvind.dk/html/nogletal/pdf/ statusnotat_0216.pdf>.

[24] "Energinet.dk. Danish wind power, old time high - 42 percent (in Danish).,". [Online]; 2016. Available: 〈http://www.energinet.dk/DA/El/Nyheder/Sider/ Dansk-vindstroem-slaar-igen-rekord-42-procent.aspx $\rangle$.

[25] Klima-. energi- og bygningsministeriet, "Energy policy report : Klima-, energi- og bygningsministerens report to Parliament on energy policy (in Danish).," 2015. [Online]; 2015. Available: 〈http://www.efkm.dk/sites/kebmin.dk/files/klimaenergi-bygningspolitik/dansk-klima-energi-bygningspolitik/energipolitiskredegoerelse/energipolitisk_redegoerelse_2015.pdf $>$.

[26] Dansk Energi, Energinet.dk, "Smart Energy - main report (in Danish).," 2015. [Online]. Available: Available: 〈http://www.energinet.dk/

SiteCollectionDocuments/Danske\%20dokumenter/Klimaogmiljo/Smart-Energy hovedrapport.pdf $>$.

[27] Danish Energy Agency, "Danish key numbers (in Danish)," [Online]. Available: 〈https://ens.dk/service/statistik-noegletal-og-kort/noegletal-og-internationaleindberetninger $>$. [accessed 16092016 ].

[28] Danish Energy Agency. "Monthly statistics : Power supply (in Danish),". [Online]; 2016. Available: 〈https://ens.dk/sites/ens.dk/files/Statistik/elmaanedsstatistik_1606.xls $>$.

[29] Energinet.dk, "Energy concept 2030 - Background report (in Danish)," 2015 [Online]. Available: 〈http://www.energinet.dk/SiteCollectionDocuments/Danske \%20dokumenter/Klimaogmiljo/Energikoncept\%202030\%20\%20Baggrundsrapport.pdf $>$.

[30] Lund H. Renewable energy strategies for sustainable development. Energy 2007;32(6):912-9.

[31] Energinet.dk, Dansk Energi (n.d), "Smart Grid i Danmark.," [Online]. Available: 〈http://www.energinet.dk/SiteCollectionDocuments/Danske\%20dokumenter/El/ Det\%20intelligente\%20elsystem\%20-\%20SmartGrid\%20i\%20Danmark \%20rapport.pdf>.

[32] Danish Energy Agency. "Energy Statistics 2013,". [Online]; 2014. Available: 〈http://www.ens.dk/en/info/facts-figures/energy-statistics-indicators-energyefficiency/annual-energy-statistics $\rangle$.

[33] Nordpool Spot. " Market data.,". [Online]; 2016. Available: 〈http://www. nordpoolspot.com/historical-market-data/>.

[34] Energianalyse EA. "Estimation of the potential for flexible power consumption in industry, trade and service (in Danish),". [Online]; 2011. Available: 〈http://www. energinet.dk/SiteCollectionDocuments/Danske\%20dokumenter/El/Kortl $\%$ C3\%A6gning $\% 20$ af $\% 20$ potentialet $\% 20$ for $\% 20$ fleksibelt $\% 20$ elforbrug $\% 20$ \%20industri.pdf.

[35] Energinet.dk; Copenhagen Economics; Quartz + Co, "Market model 2.0: Technical background report (in Danish)," 2015. [Online]. Available: 〈https://energinet.dk/-/ media/Energinet/Publikationer-TLU/Markedsmodel/Teknisk-baggrundsrapportmarkedsmodel-20.pdf>.

[36] Lund Nyeng, Grandal Sørensen, Bedtsen lRay, Larsen Mastop, Judex LeimgruberKok, MachDougall. "EcoGrid EU - A Prototype for European Smart Grids. Deliverable D6.7 Overall evaluation and conclusion,". [Online]; 2016. Available: 〈http://www.eu-ecogrid.net/images/Documents/D6.7_160121_Final. pdf $>$.

[37] Gils H. Assessment of the theoretical demand response potential in Europe. Energy 2014;67:1-18.

[38] Kwon PS, Østergaard P. Assessment and evaluation of flexible demand in a Danish future energy scenario. Applied Energy 2014;134:309-20.

[39] Danish Statistics. BOL105: Housing for areas, type, use, heating technology, bath room, housing standare and number of children (in Danish), [Online]; 2016. Available: 〈http://www.statistikbanken.dk/bol105〉.

[40] Hveem P, Hansen R. "Deactivation potential in residential and commercial buildings. Energy Norway (in Norwegian); 2000. 
[41] T. C. Group. "Forbrukstilpasninger hos store kunder med timesmåling" Consultancy report prepared for NVE (in Norwegian); 2016.

[42] Kipping A, Trømborg E. "Hourly electricity consumption in Norwegian households Assessing the impacts of different heating systems. Energy 2015;93:655-71.

[43] Kipping A, Trømborg E. "Modeling and disaggregating hourly electricity consumption in Norwegian dwellings based on smart meter data. Energy Build 2016;118:350-69.

[44] Kipping A, Trømborg E. Modeling houly consumption of electricity and district heat in non-residential buildings. Energy 2017;123:473-86.

[45] T. C. Group. "Forbrukerfleksibilitet of styrning av forbruk - pågående aktiviteter. Report to NVE (in Norwegian) - NVE report2015/07,"; 2015.

[46] Meland P, Stamer Wahl T, Tjeldflåt A. Consumer flexibility in the Norwegian power market. Report 7.The Norwegian Water Resources and Energy Directorate (n Norwegian); 2006.

[47] Sæle H, G. O.S. Demand Response From Household Customers: Experiences From a Pilot Study in Norway; 2011.

[48] Statistics Finland. [Online]; 2016. Available: 〈www.stat.fi $\rangle$.

[49] Fingrid Oyj Ltd., [Online]. Available: 〈www.fingrid.fi $\rangle$.

[50] Pihala H, Farin J, Kärkkäinen S. Survey of demand flexibility potential in finnish industries. Espoo, Finland: VTT Prosessit; 2005 Aug (Report No.: PRO3/ P3017/05), (in Finnish); 2005.

[51] Evens C, Kärkkäinen S, Pihala H. "Distributed resources at customers' premises. Espoo, Finland: VTT; 2010 Feb (Report No.: VTT-R-06411-09).,"; 2010.

[52] Federation of Finnish Industries and Energy Industries, Estimate of electricity demand in Finland in 2030, Helsinki, (in Finnish); 2009.

[53] Lund PD, Lindgren J, Mikkola J, Salpakari J. Review of energy system flexibility measures to enable high levels of variable renewable electricity. Renew Sustain Energy Rev 2015;45:785-807.

[54] Häkli J-P SG. Interviewee, Personal communication. [Interview]; 2014.

[55] Salpakari J, Mikkola J, Lund P. "Improved flexibility with large-scale variable renewable power in cities through optimal demand side management and power-toheat conversion.," Energy Conversion and Management (Accepted for publication). 2016.

[56] Elering AS. "Security of Supply Report 2016,"; 2016.

[57] "Statistics Estonia,". [Online]; 2016. Available: Statistics Estonia (2016). 〈www. stat.ee $>$.

[58] Elering AS, "Elering - Transmission capacity allocation in Estonia," [Online].
Available: 〈http://elering.ee/ulekandevoimsuste-jaotamine-eestis-3/〉. [accessed 1 $112016]$.

[59] Rosin. et al, "Analysis of Large Electricity Consumers Demand Profiles to Determine Implementation of Demand-Side Management Measures,"; 2016.

[60] Pöyry. "Demand-side response as source for flexibility," Elering, Tallinn; 2015.

[61] Gothia Power, "Executive Summary of Project "Feasibility stufy on the interconnection variants for the integration of the Baltic States to the EU internal electricity market"," Gothia Power; 2015.

[62] "New paper plants planned to completed by 20222, " 27 01. [Online]; 2017. Available: 〈http://www.aripaev.ee/uudised/2017/01/27/miljardiprojektisttselluloositehas-voib-kerkida-emajoe-kaldale $>$. [Accessed 27 January 2017].

[63] Ministry of Economics of Republic of Latvia. Information Report: Republic of Latvia National Renewable Energy Action Plan for implementing Directive 2009/28/EC of the European Parliament and of the Council of 23 April 2009 on the promotion of the use of energy from renewable sources and amending and, subsequently repealing Directives 2001/77/EC and 2003/30/EC by 2020, 2010, p. 103.

[64] Blumberga A, Lauka D, Barisa A, Blumberga D. Modelling the Baltic power system till 2050. Energy Convers Manag 2016;107:67-75.

[65] EC.Europe. "EU energy country reports. Latvia," 2014. [Online]; 2014. Available: 〈https://ec.europa.eu/energy/sites/ener/files/documents/2014 countryreports latvia.pdf $\rangle$.

[66] Bariss U, Kamenders A, Vitolins B, Blumberga D. "Energy efficiency results of Smart metering pilot in a context of Cost Benefit analysis of smart meters in Latvia," In: Conference Proceedings of the 27st international conference on efficiency, cost, optimization, simulation and environmental impact of energy systems; in ECOS 2014; 2014. p. 2168-77.

[67] Bariss U, Dandens A, Blumberga D. "Smart Meters as Enablers for Feedback Information Induced Energy Efficiency and Demand Response: Case Analysis in Latvia.," In: IEEE Proceedings of the 5th international conference on power engineering, energy and electrical drives (POWERENG): Proceedings, Latvija, Rīga, 11.-13. maijs, 2015. Riga Technical University; 2015, p. 69-73.

[68] National Renewable Energy Action Plan of Lithuania, "p.p. 135,".

[69] Gils HC. Economic potential for future demand response in Germany - modeling approach and case study. Appl Energy 2016;162:401-15.

[70] Sia partners. "Demand Response : A study of its potential in Europe," 0502. [Online]; 2015. Available: 〈http://energy.sia-partners.com/demand-responsestudy-its-potential-europe $\rangle$. [Accessed 01 March 2018]. 